\title{
A STUDY OF PROS AND CONS OF US HEDGE FUND REGISTRATION
}

\author{
Ye $\mathrm{Li}^{*}$
}

This research paper will begin with the background introduction on what hedge funds are and how they currently are exempted from most US securities regulation. This paper will also examine benefits and concerns of hedge funds in the US financial markets. Finally, this paper will address whether that hedge fund registration should be registered with the SEC.

INTRODUCTION 883

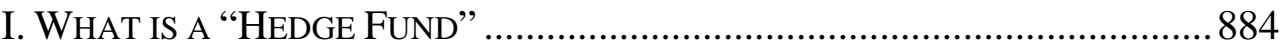

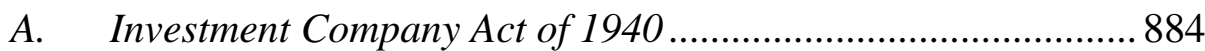

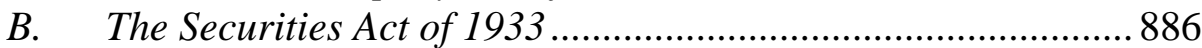

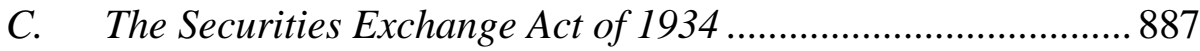

D. The Investment Advisers Act of 1940......................................... 887

II. SEC's PREvious AtTEMPt to Regulate Hedge Funds: The "Hedge

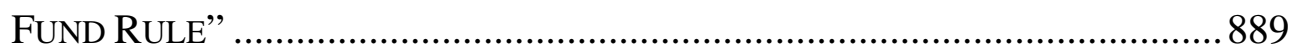

III. The Pros AND CONS Of HEDGE Fund REGISTRATION ........................... 889

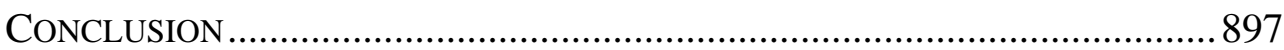

\section{INTRODUCTION}

While the average investor may not understand the complex industry of hedge funds, regulators in the United States have been aware of them for a long time, and the regulators persistently attempted to regulate them. One of the main regulatory pushes has been to force the hedge funds to register. The SEC first attempted this by promulgating the "hedge fund rule" in December, 2004. While the rule was later vacated by a D.C. circuit court, ${ }^{1}$ legislators have picked up where the SEC failed. Two bills are currently being considered that would require hedge fund advisers to register with securities regulators. ${ }^{2}$ One of them would amend the Investment Advisors Act of 1940 to allow the SEC to require hedge funds to register with the agency. ${ }^{3}$ The second bill would require pension plans to disclose their

\footnotetext{
* Ye Li, Lecturer in Law, Jiangxi University of Economics and Finance, China. Research fields: civil and commercial law, competition law.

${ }^{1}$ See Infra Section III.

${ }^{2}$ Hedge Fund Registration Still a Possibility, Investment News, Sep. 4, 2007. Available at http://www.investmentnews.com/apps/pbcs.dll/article?AID=/20070904/FREE/70831025/1/INRegulatoryAlert03.

${ }^{3}$ HR 2586.
} 
investments in hedge funds, essentially doing the same thing. ${ }^{4}$

Hedge funds regulations present a unique risk reward scenario for US regulators. If regulate them too tightly, many hedge funds will likely flee to foreign countries in order to escape costly and burdensome regulation, costing the US many of the benefits of having US based hedge funds, and leaving with little to no oversight in countries eager to ease the regulatory burden in order to attract more hedge funds. On the other hand, allowing hedge funds to operate uncontrolled and uncheck presents risks to not only investors in the funds, but to the broader markets as a whole. To better understand this dichotomy, one must understand both the benefits and concerns over hedge funds.

\section{WHAT IS A “HEDGE FUND”}

Hedge funds are notoriously difficult to define. In its simplest definition, hedge funds simply mean a "professionally managed pool of assets used to invest and trade in equity securities, fixed-income securities, derivatives, futures and other financial instruments." " Hedge funds employ a variety of trading strategies, some combining an assortment of techniques and investment vehicles, while others will specialize in only several strategies and may focus even on only one investment vehicle (for example, engaging in only currency trading). ${ }^{6}$ Thus, each hedge fund is vastly different, depending on the investment philosophies and strategies of its investment advisor.

Hedge funds are typically exempt form federal securities laws, avoiding regulation and registration under the Securities Act of 1933, the Securities and Exchange act of 1934, the Investment Advisors Act of 1940, and the Investment company act of 1940. Through various exceptions and other techniques, hedge funds successfully avoid many of these Acts requirements.

\section{A. Investment Company Act of 1940}

The Investment Company Act of 1940 (hereinafter "Company Act”), defines an investment company as an issuer which "is or holds itself out as being engaged primarily...in the business of investing, reinvesting, or trading in securities" or "is engaged...in the business of investing,

\footnotetext{
${ }^{4}$ S 1402.

${ }^{5}$ Douglas L. Hammer, U.S. Regulation of Hedge Funds, 1 (2005).

${ }^{6}$ Supra Note 7, at 1.
} 


\section{A STUDY OF PROS AND CONS OF US HEDGE 885}

reinvesting...or trading in securities, and owns...investment securities having a value exceeding 40 per centum of the value of such issuer's total assets..."7 Clearly, most hedge funds fall into both these definitions, which would open them up to numerous rules and regulations on their funds.

Under the Company Act, a registered investment company is "subject to technical, complex and extensive substantive regulation of its activities." To be able to sell securities in the United States, the investment company must be registered under the Act. ${ }^{9}$ Registration requires the filing of a registration statement, which requires much of the same information required to be filed in the registration statements under the 1933 and 1934 Acts. ${ }^{10}$ However, the Company Act also requires that, investment company disclose their policy on a number of specific issues, including such things subjects as diversification, borrowing and lending money, issuance of senior securities, and investing in real estate or commodities. ${ }^{11}$ These policies may only be changed by a vote of the majority of shareholders. ${ }^{12}$ Obviously, these registration requirements impose high costs and limitations on hedge funds, but most are able to avoid registration under the act thanks to two exceptions.

First, Section 3(c)(1) of the Company act excludes from the definition of an investment company any issuer that does not have more than 100 investors and does not nor plans to make a public offering of its securities. ${ }^{13}$ In conjunction with Section 4(2) of the Securities act, offerings made under the safe harbor found within Rule 506 of Regulation D (discussed later) are found not to involve a public offering under 3(c)(1). ${ }^{14}$ In addition, corporate investors are counted as one investor, so long as the investor does not own more than ten percent of the outstanding voting securities of the Section 3(c)(1) fund. ${ }^{15}$ The second exception involves § 3(c)(7) of the Company Act, which excludes from the definition of investment company any fund that is only held by "qualified purchasers." ${ }^{16}$ Included in the definition of a

\footnotetext{
${ }^{7}$ Company Act $\S 3(a)(1), 15$ U.S.C. § 80a-3(a)(1).

${ }^{8}$ U.S. Regulation of Hedge Funds, supra note 4. Investment Companies that fail to register are subject to both criminal and civil penalties, and even private actions that could result with them having to refund all advisory fees and losses. 15 § 80a-42(d)-(e).

${ }^{9} 15$ U.S.C. $\S 80 \mathrm{a}-7(\mathrm{a})$.

${ }^{10} \S 8(\mathrm{c})$, Rules 8b-23, 8b-23.

11 Louis Loss, Joel Seligman \& Troy Paredes, Securities Regulation 357-58 (4th ed. 2006). 15 U.S.C. § 80a-8(b).

${ }^{12}$ Louis Loss, supra Note 13, at 358.

13 15 U.S.C. § 80a-3(c)(1).

${ }^{14} 15$ U.S.C. $\$ 77(d)(2)$.

${ }^{15}$ Company Act Rule 3c-1, 17 C.F.R. § 270.3c-1.

${ }^{16} 15$ U.S.C. § 80a-3(c)(7).
} 
"qualified purchasers" individual who owns more than five million dollars in investments. ${ }^{17}$

\section{B. The Securities Act of 1933}

The Securities act of 1933 primarily regulates the initial offering and sale of securities (as opposed to the securities trading on the secondary market). ${ }^{18}$ To sell securities to investors, the Securities Act requires that the securities be registered with the SEC and that all purchasers must receive a prospectus contain information about the issuer and the securities being sold. The interests sold by hedge funds to investors are typically are considered "securities," and the hedge fund must register the offering and sale of the securities unless there is an exemption from registration for the hedge fund to rely on. ${ }^{19}$ Indeed, hedge funds offering securities in the United States usually rely on two exemptions to avoid registration: (1) the private offering exemption under Securities Act Section 4(2); and (2) Regulation D Rule 506 safe harbor.

Section 4(2) under the Securities Act exempts "transactions by an issuer not involving any public offering" from the registration requirements of Securities Act Section 5. While the Securities Act itself does not define a "public offering," courts have generally looked to weather the particular investors can "fend for themselves" 20 in answering this question. Courts will look to the offeree, and determine if they have had access to information about the fund or have received disclosures similar to the information required to be contained within a registration statement under the Securities Act. Courts wills will also look to the investor sophistication, examining their investing experience, wealth, the size of the offering as a whole, and the manner in which the offering was made, in order to determine if the investor was able to "fend for themselves." 21

In addition to Section 4(2), the SEC has promulgated a safe harbor, Rule 506 under Regulation D, in order to ensure that an issuer has a Section 4(2) exemption. To rely on Rule 506 of Regulation D, a issuer must comply with a number of requirements. First, the issuer may not engage in any advertising or general solicitation in the offering of its securities. ${ }^{22}$ Second,

\footnotetext{
${ }^{17} 15$ U.S.C. § 80a-2(a)(51)(A).

${ }^{18}$ Securities Regulation, supra Note 13, at 327.

${ }^{19}$ U.S. Regulation of Hedge Funds, supra Note 4, at 111-12.

${ }^{20}$ SEC v. Ralston Purina Co., 346 U.S. 119, 125 (1953). U.S. Regulation of Hedge Funds, supra Note 4 , at 112 .

${ }^{21}$ U.S. Regulation of Hedge Funds, supra Note 4, at 114.

${ }^{22}$ Regulation D Rule 502(c), 17 C.F.R. § 230.502(c).
} 


\section{A STUDY OF PROS AND CONS OF US HEDGE 887}

the issuer must limit its sale to no more than thirty thirty-five non-accredited investors, but may sell to an unlimited number of accredited investors. Accredited investors include "individuals who have a net worth...above $\$ 1,000,000$, or have income above $\$ 200,000$ in the last two years... and a reasonable expectation of reaching the same income level in the year of investment." ${ }^{23}$ In addition, certain institutional investors (i.e., corporations, banks, etc.) that have assets over five million dollars are considered accredited investors. ${ }^{24}$ Non-accredited investors must "have sufficient knowledge and experience in financial and business mattes to be capable of evaluating the merits and risks of the prospective investment" in order to purchase securities under this exemption. ${ }^{25}$ In addition to these requirements, Rule 506 requires that, certain disclosures be delivered to non-accredited investors before the sale, and places certain restrictions on the resale of the securities obtained under Rule 506.

\section{The Securities Exchange Act of 1934}

The Securities Exchange Act regulates secondary trading markets, and could possibly apply to hedge funds. A hedge fund may be regulated under the Exchange Act: (1) if they fall within the definition of either a "dealer" or (2) if they have over 500 holders of record and have assets in excess of 10 million dollars. However, due to various exemptions, hedge funs are able to avoid the majority of the Exchange Act 1934.

\section{The Investment Advisers Act of 1940}

Under the Investment Advisers Act, an "investment adviser" is "any person who, for compensation, engages in the business of advising others... as to the value of securities or as the advisability of investing in, purchasing, or selling securities. ${ }^{26}$ Nearly all hedge fund advisors would fall under this definition. ${ }^{27}$ Without an exemption, almost all hedge fund advisors thus would be forced to register with the SEC.

Investment advisors are required to keep prescribed records of there books, which the SEC is allowed to make examinations of if they deem it

\footnotetext{
${ }^{23}$ Regulation D Rule 501(a), 17 C.F.R. § 230.501(a).

${ }^{24}$ Regulation D Rule 501(a), 17 C.F.R. § 230.501(a).

${ }^{25}$ U.S. Regulation of Hedge Funds, supra Note 4, at 124.

${ }^{26}$ Advisors Act § 202(a)(11), 15 U.S.C. § 80b-2(a)(11).

${ }^{27}$ Staff Report to the United States Securities and Exchange Commission, Implications of the Growth of Hedge Funds, September 20, 2003.
} 
necessary for the protection of investors, at any time. ${ }^{28}$ They must keep accurate and current the following books and records relating to its investment advisory business, including, for example: (i) records of cash receipts and disbursements, asset, liability, reserve, capital, income and expense accounts; (ii) copies of all written communications received and copies of all written communications sent by such investment adviser relating to any advice or recommendations involving securities; (iii) a copy of the investment adviser's code of ethics; and (iv) a record of any decision, and the reasons supporting the decision, to approve the acquisition of securities. $^{29}$

In addition, the investment advisor is required to keep the records arranged in easy location, access, and retrieval of any particular record and to promptly provide any of them to the SEC if requested. ${ }^{30}$ Furthermore, the Investment Advisors act requires that, registered investment advisors both adopt and enforce a "code of ethics." 31

However, under the investment Advisors Act of $\S 203(b)(3)$, must hedge funds are able to qualify under an exemption. Under the § 203(b)(3) exemption, the Investment Advisors act excludes any investment advisor that (i), have fewer than 15 clients during the past 12 months, and (ii) who do not hold themselves out generally to the public as an investment advisor, and (iii) are not advisers to a registered investment company, are exempt from registration under the Investment Advisers Act.

The Investment Advisors act does not explain how to determine who is a "client" for the purpose of the exception. However, by SEC rules, a "legal organization" is deemed to be a "single client." ${ }^{32}$ More simply put, the pooled money from investors that creates the hedge fund is the "single client," qualifying as a legal organization, so long as the legal organization "receives investment based on its investment objectives rather than the individual investment objectives" of its owners. ${ }^{33}$ Therefore, a hedge fund advisor may manage up to 14 hedge funds without having to register with the SEC as an investment advisor.

\footnotetext{
${ }^{28}$ See 15 U.S.C. 80b-4 (stating requirement that registered investment advisers keep records as defined in).

${ }^{29}$ Advisors Act Rule 204-2.

3017 CFR 275.204-2 (2000) (explaining in detail specific records which must be kept).

${ }^{31}$ Advisers Act rule 204A-1, 17 C.F.R. § 275.204.

${ }^{32}$ Rule 203(b)(3)-1.

${ }^{33} \mathrm{Id}$.

${ }^{34}$ SEC report, supra Note, at 21.
} 


\section{A STUDY OF PROS AND CONS OF US HEDGE 889}

\section{SEC’s Previous Attempt to Regulate Hedge Funds: The “Hedge FUND RULE”}

In 2004, the SEC made its first attempt to regulate hedge funds by changing the rules of the Advisors Act in attempt to make hedge fund advisors to register under the Act. Under the Hedge Fund Rule (the "New Rule"), most hedge advisers would have been required to register as investment advisers with the SEC. As discussed above, most hedge fund advisors had fallen within the $\S 204(b)(3)$ exemption allowing hedge fund advisors advising less than 15 funds to avoid falling under the act, counting only the fund, not the investors into the fund, as a single "client." The New Rule changed how the SEC would define who a "clients" is.

Under the New Rule, investment advisors would have to "lookthrough" the fund, and count each owner of an interest or share in the fund as a "client." 35 Thus, any fund that has 15 or more investors would no longer fall under the previous exemption, being forced to register. By being forced to register, hedge fund advisors had to open their records to the SEC, as discussed above, and also could not charge their clients a performance fee unless such clients met a minimum net worth requirement, where the client was worth at least 1.5 million or had at last 750,000 under management with the advisor. ${ }^{36}$

The rule however was short-lived. The rule was quickly challenged by Philip Goldstein, a hedge fund manager who brought suit to challenge the SEC's interpretation of $\S$ 203(b)(3). The court ultimately found that, the SECD had failed to "justify departing from its own prior interpretation of $\S$ 203(b)(3)," explaining that, the rule was "completely arbitrary.” Thus, while the Hedge Fund Rule was short-lived, it clearly represented that, SEC's desire to regulate hedge funds by forcing them to register under the Advisors Act.

\section{The Pros ANd Cons of Hedge Fund Registration}

The SEC decided to require registration of certain hedge fund advisors under the Investment Adviser Act of 1940. While this interpretation of the act was thrown out in court as a stretch of legal authority, members of both houses of Congress are working to require hedge fund managers to register with the SEC.

Some of the SEC commissioners who originally required the

\footnotetext{
3517 C.F.R. § 275.203(b)(3)-2(a).

${ }^{36}$ Goldstein v. SEC, 451 F.3d 873, 877 (2006).
} 
registration (but notably not all) claimed that, the registration will prevent fraud and help control the industry. The question is whether there is any significant level of fraud, and if registration is the correct way to put reigns on hedge funds. If registration is not an appropriate measure, then is it a waste of taxpayer money to implement, or even worse, will it take their attention away from more pressing matters. ${ }^{37}$

Under the ruling the SEC changed the definition of "client". Hedge fund managers originally saw each fund as a "client", but the SEC proclaimed (only to later be corrected in court) that each individual investor involved was a "client". Nearly every fund had more than fifteen investors, thereby eliminating the use of the registration exception for advisors with less than fifteen clients, and was now required to register with the SEC. ${ }^{38}$

Under the current version of Section 203(b)(3) of the Advisers Act and the rules there under, an investment adviser is not required to register with the SEC if:

(i) it has fewer than 15 advisory clients in any 12- month period;

(ii) does not hold itself out to the public as an investment adviser; and

(iii) has $\$ 25$ million or more in assets under management. ${ }^{39}$

The SEC claimed that, because hedge funds have gone "mainstream" a need to for further regulation now exists. The justifications that they put forth, however, simply do not hold up. One such justification is the increasing amount of fraud in hedge funds. They claimed that registration of managers will prevent fraud. ${ }^{40}$

First there is no evidence that there is an increasing level of fraud.

"The 2003 Staff Hedge Fund Report found no retailization and no significant increase in fraud. These conclusions were consistent with the views expressed at the Commission's May, 2003 roundtable, at which 60 panelists, including representatives of federal, state and foreign government regulators, securities industry professionals, and academics testified." ${ }^{41}$

The FCC had no justification for its accusation of "retailization" and increasing fraud. While there is some fraud in the hedge fund industry, this is true of every industry in the United States. The amount of fraud is simply not enough to warrant further SEC regulation. After all, the current

\footnotetext{
${ }^{37}$ Astarita Esq. \& Mark J., Registration of Hedge Fund Managers: Bureaucracy without Benefit. Available at http://www.seclaw.com/docs/New\%20Hedge\%20Fund\%20Advisor\%20Rule.htm. ${ }^{38} I d$.

${ }^{39} \mathrm{Id}$.

${ }^{40} \mathrm{Id}$.

${ }^{41} I d$.
} 


\section{A STUDY OF PROS AND CONS OF US HEDGE 891}

regulations and laws dealing with fraud already cover the types of fraud that the SEC is worried about. The SEC already has jurisdiction over every hedge fund that commits securities fraud. ${ }^{42}$

There is also no evidence that registration would actually prevent fraud. The defendants from Enron and Tyco were registered, and this did nothing to stop their fraud. Beyond preventing fraudulent action, registration also did nothing to detect of stop the action in Enron or Tyco. ${ }^{43}$ Registration also did nothing to prevent the mutual funds timing scandal. ${ }^{44}$ Adding registration requirements does not seem to be an appropriate way to fight fraud.

As Kevin O’Connor, U.S. Attorney for the District of Connecticut put it:

“The bottom line is, when you look at it as a prosecutor”, O’Connor said, "certainly registration is an effective way to monitor. But most of the times, it's the victims. And you know, if you're really intent on committing a fraud, you can avoid detection through registration. So registration, without taking an opinion on 'it's good or bad', it's not the silver bullet that's going to prevent fraud...A lot of the industries with fraud are registered, regulated industries by the Securities and Exchange Commission., 45

The SEC is also concerned with "retailization" of hedge funds, or that they are being sold to the masses. This type of solicitation is already taken care of under current regulations. Hedge funds do not accept un-accredited investors. Investors that do not earn under $\$ 200 \mathrm{k}$ a year with a net worth of over a million can not get into a hedge fund. The level of sophistication of investors in hedge funds is high, and therefore fraud should be less of a concern. As for "qualified" clients, there are not so many people in the United State with a net worth of \$1.5 million and \$175,000 for an advisor to invest that they should be considered the general public. If there are common people involved in hedge funds, it is only because the SEC is not enforcing current regulations. ${ }^{46}$

The SEC staff cites a potential, but concedes that it has not observed any retailization. ${ }^{47}$ They say that, hedge funds have strong incentives to

\footnotetext{
${ }^{42} I d$.

${ }^{43} I d$.

${ }^{44}$ Pearlstein Stephen, Hedge Fund Registration. Available at http://www.washingtonpost.com/wpdyn/content/discussion/2005/10/18/DI2005101800731.html.

${ }^{45}$ Lee Melissa. Hedge Fund Registration: No Silver Bullet, (May 23, 2007). Available at http://www.cnbc.com/id/18819084.

${ }^{46}$ Supra Note 1.

${ }^{47}$ SEC Staff Report, Implications of the Growth of Hedge Funds, 78. Available at http://www.sec.gov/news/studies/hedgefunds0903.pdf.
} 
place their own high restrictions on qualified investors, but that more and more qualified investors are getting into the hedge fund market. ${ }^{48}$ This should not be characterized as "retail" just because more and more superrich investors are getting involved. Growth in the industry should not have to be viewed as a problem.

The SEC cited the media to support an increase in investors that are new to hedge funds. This simply means that, this investment avenue is growing, and not that anything improper is going on. Because of the hedge fund boom, more sophisticated wealthy individuals are investing. ${ }^{49}$

The SEC maintained that, $20 \%$ of private and public pension funds have invested in hedge funds. These, however, are professional money managers who are already regulated by the $\mathrm{SEC}^{50}$ (tend to invest less than $1 \%$ (cite)).

If SEC does not have the budget or resources to prevent the current fraud, how will it be able to implement additional regulations? The SEC has a history of reacting to fraud, rather than preventing it. The most significant instances of fraud in the past decade were all uncovered by whistle-blowers and private attorneys and not the SEC. Investigation of registered advisors is either ineffective, or is not significant enough in the investment industry, and therefore does not seem to be a valid avenue of fraud prevention. ${ }^{51}$

Besides wasting the SEC's precious resources, this is also a heavy burden on hedge funds, and therefore, also on their investors. Hedge funds would have to provide basic information to the SEC as well as hire a chief compliance officer. Hedge funds would also be subject to random inspections. While these may seem like worthwhile pursuits, overall registration hurts managers ability to perform. ${ }^{52}$

Registration would also make starting a new hedge fund extremely difficult. Registration increases the start-up costs tremendously, and is therefore very prohibitive. Legal fees, record keeping costs, staffing costs as well as related expenses can add up very quickly. ${ }^{53}$ Some claim that, registration will cost their hedge funds $\$ 500,000$ a year, and destroy their ability to act in a timely manner with a fast paced market. ${ }^{54}$ Perrie Weiner, a partner at DLA Piper who specializes in hedge funds, says:

\footnotetext{
${ }^{48} I d$. at 81 .

${ }^{49} \mathrm{Id}$.

${ }^{50} I d$.

${ }^{51} \mathrm{Id}$.

${ }^{52}$ Cantrell Amanda. Government Catches up with Hedge Funds. Available at http://money.cnn.com/2006/02/01/markets/hedge_registration/.

${ }^{5} 3 \mathrm{Id}$.

${ }^{54}$ Oserley Dale A., Regulating Hedge Funds, 1 ENTREPREN. Bus. L.J. 1. 10.
} 


\section{A STUDY OF PROS AND CONS OF US HEDGE 893}

"There is nothing material to be gained from any enhanced regulation of hedge funds, other than to raise the cost of doing business, which ultimately would be borne by the investors who likewise see no benefit. The SEC already has more than adequate means in its available legal arsenal to investigate and prosecute any hedge fund or investment adviser that, it believes has violated the law."55

Funds with more than $\$ 30$ million would have to register, while firms with more than $\$ 25$ million have the option. Funds could also skirt registration by "locking up" investors money for more than two years and refusing to take new investors for that period. Unless these funds were already contemplating closing, however, this does not seem to be a viable option for most funds who wish to grow their business. ${ }^{56}$

The SEC's own study found that there is "no evidence indicating that, hedge funds or their advisers engage disproportionately in fraudulent activity." Most of the hedge fund fraud already prosecuted by the SEC involves advisors with less than \$25 million, who would not even be affected by the new interpretation. ${ }^{57}$

Registration also provides investors with a false sense of security in this risky business. Especially for the time period when hedge funds would be newly registered, investors might view the registration as a minimization of the risk when in fact the two are mutually exclusive. ${ }^{58}$

Hedge funds are able to disperse risk and add liquidity to the market because they are flexible in their investment strategies. ${ }^{59}$ Registration seriously hurts this flexibility. Roundtable discussions led to the SEC staff to applaud hedge fund flexible investment strategies in their avoidance of loss in a falling market. They said that, while it is unclear why other registered investment institutions do not use these strategies, registration may be partly to blame. ${ }^{60}$

More regulation will also cause more hedge funds to move off shore where they are even further from the watchful eye of the SEC. ${ }^{61}$ Moving offshore will allow these funds to better avoid registration, but will also take business away from the United States. ${ }^{62}$

\footnotetext{
${ }^{55}$ Moyer Liz, Grassley Goes after Hedge Funds, (May 15, 2007.) Available at http://www.forbes.com/wallstreet/2007/05/15/hedge-fund-sec-biz-wall-cx_lm_0516grassley.html.

${ }^{56}$ Supra Note 16.

${ }^{57}$ Supra Note 1.

${ }^{58}$ Supra Note 16.

59 Supra Note 18 , at 6.

${ }^{60}$ Supra Note 11 , at 87.

${ }^{61}$ Weiner Pierre, Hedge Fund Regulation: Enough Already, (April 13, 2007). Available at http://www.forbes.com/2007/04/13/hedge-fund-regulation-op-ed-cx_pw_0413hedge.html.

${ }^{62}$ Supra Note 18, at 11.
} 
Registration of hedge funds will also encourage mergers between hedge funds. While before managers were limited in the number of "clients" they could have by the fear of having to register; now they would have no reason not to make large mergers. ${ }^{63}$

While hedge fund registration may not be a wholly terrible idea, it is not an appropriate measure of preventing fraudulent managers. The SEC claims that, registration will provide a way to track the hedge fund industry, conduct investigations, deter wrongful conduct, and to screen individuals associated with advisors for problems such as felony convictions. ${ }^{64}$

The SEC, as well as investors in general, has to rely on private organizations for information regarding how hedge funds are run, their assets, or who controls them. ${ }^{65}$ The SEC says that, this information is needed to properly asses the market, as well as protect it from huge potential loss, they then, however, discuss the powerful incentives to achieve positive performance as a reason to worry about mispricing. ${ }^{66}$ Valuation of hedge funds is a concern because without disclosure of their investment portfolios, it is hard to make an independent valuation. This also inhibits the ability to value other registered financial organizations who have invested in these hedge funds. The SEC cites pension plans as the most pressing example of this. ${ }^{67}$ This view, however, does not take into consideration the fact that these types of institutions are accredited investors with sophisticated managers. If financial institutions like pension plans were not already confident in their ability to evaluate the risk, they would not be investing in hedge funds. In any event, the SEC's own study claims that registration would not have the effect of increasing disclosure of portfolios. ${ }^{68}$

One solution to this problem is simply requiring hedge funds to keep better records. Many of the desired effects could also be achieved by having hedge funds complete annual questioners. This solution is simple, would require little effort and would most likely not be resisted by the hedge fund industry. It would create a win / win situation. ${ }^{69}$

The SEC is also concerned that, hedge fund managers are not adequately disclosing conflicts of interest. This concern lies not with hedge fund managers favoring other clients, but because of the usual incentive

\footnotetext{
${ }^{63} \mathrm{Id}$. at 11 .

${ }^{64}$ Supra Note 16.

${ }^{65}$ Supra Note 11, at 77.

${ }^{66}$ Supra Note 11, at 79.

${ }^{67}$ Supra Note 11, at 81.

${ }^{68}$ Supra Note 11, at 92.

${ }^{69}$ Registration Not Only Way for Hedge Funds, (April 11' 2007). Available at

http://www.reuters.com/article/GlobalHedgeFundandPrivateEquity07/idUSN1041079820070411.
} 


\section{A STUDY OF PROS AND CONS OF US HEDGE 895}

system in place with hedge funds, they might favor the hedge funds over other clients. The SEC also cites limited disclosure of arrangements with prime brokers as a potential problem. ${ }^{70}$

The SEC's final concerns are with general solicitation. ${ }^{71}$ Assuming that, this is happening, the SEC fails to connect how registration would prevent solicitation. It is already against the law for hedge funds to engage in solicitation, and if the SEC can't control this now, how do they expect registration to curb the people who are knowingly and willingly engaging in a prohibited activity? Registration and random inspections would seem to provide more of an incentive to hide this activity.

If the SEC wants to change who is investing in hedge funds, they need only change the investment criterion. This would clearly be more effective than registering managers. This has its downsides too as such a change would cut people out of the market. If people with the money to invest in hedge funds now aren't sophisticated enough then who is? This also has the effect of propagating the rich get richer stereotype, and cutting people out of a market just because it is risky. ${ }^{72}$

Since the SEC ruling was overturned, 275 hedge fund managers have deregistered. Many more may not have deregistered simply because they have not picked up their phone to call their lawyers. This suggests that, registration anti-fraud report was not important to their clients. ${ }^{73}$ There is also evidence, however, that funds that, registered in 2006 outperformed those who did not. Registering could be seen as a sign of quality by investors, or it could simply be redundant information. Financial institution and equity investors are generally able to distinguish operational risk without the aid of SEC disclosure forms, however evidence shows that, share investors are less able to distinguish risk. One reason that this may be true is that, share investors have less access to expensive databases such as TASS. It is also important to note that, the SEC ADV filings are available for free. ${ }^{74}$ This suggests that, SEC disclosure could be a very good thing for the less-sophisticated investor.

Two bills on Capitol Hill would give the SEC its authority back. HR 2586 (the Security and Exchange Commission Restoration Act of 2007) and

\footnotetext{
${ }^{70}$ Supra Note 11 , at 84 .

${ }^{71}$ Supra Note 11 , at 88.

${ }^{72}$ Holt Christopher, SEC Hedge Fund Registration: Investors are Livid, (February 5, 2007). Available at http://seekingalpha.com/article/26027-sec-hedge-fund-registration-investors-are-livid.

${ }^{73}$ Ribstein Larry, Hedge Fund Registration Flunks the Market Text, (December 15, 2006). Available at http://busmovie.typepad.com/ideoblog/2006/12/hedge_fund_regi.html.

${ }^{74}$ Lessons from Hedge Fund Registration, (November 16, 2006). Available at http://business.rutgers.edu/download.aspx?id=1317.
} 
S 1402 (the Hedge Fund Registration Act of 2007), would require hedge funds to register with the SEC. HR 2586 would also require pension plans to disclose their investments in hedge funds. ${ }^{75}$

S 1402 is championed by Senator Chuck Grassley. ${ }^{76}$ While only in the first stages of the legislative process, the bill has stirred up a lot of concern. ${ }^{77}$ Grassley says that, there is a greater need for disclosure. He feels that, while secrecy might be acceptable for the super-rich investor, it is not acceptable when an "average joe" does not know about the risks that pension funds are taking with hedge funds. He has proposed this bill as an amendment to a larger bill that deals with homeland security stating that, it is relevant because hedge funds can have terrorist links. The amendment would require hedge fund managers to register with the SEC as advisors unless they:

“(1) had \$50,000,000 or less in assets under management, (2) had fewer than fifteen clients, (3) did not hold himself out to the public as an investment advisor, and (4) managed the assets of fewer than fifteen investors, regardless of whether the investors participate directly or through a pooled investment vehicle, such as a hedge fund" ${ }^{78}$ Grassley simply states that, the SEC needs to know "who is controlling these massive pools of money." ${ }^{, 79}$ The overarching fear is that average investors are becoming progressively more exposed to serious fiscal loss. ${ }^{80}$

A final problem with registration is that rules beget rules. Because these regulations are inadequate to stop fraud, they will be replaced with harsher and harsher regulations. ${ }^{81}$ The true reason for regulation is that, people do not like the fact that, hedge funds can make an enormous amount of money very quickly. People fear the wealth gap, and as long as hedge funds continue to make money, there will be people who try to stop them. The problem with this social concern is that making money in the market is a good thing.

\footnotetext{
${ }^{75}$ Hedge Fund Registration Still Possibility, (September 4, 2007). Available at http://www.investmentnews.com/apps/pbcs.dll/article?AID=/20070904/FREE/70831025/1/INRegulatoryAlert03.

${ }^{76}$ Waddell Melanie, New Grassley Bill Would Require Hedge Fund Registration, (May 16, 2007). Available at http://www.investmentadvisor.com/article.php?article=7731.

${ }^{77}$ S. 1402: Hedge Fund Registration Act of 2007. Available at http://www.govtrack.us/congress/bill.xpd?bill=s110-1402.

${ }^{78}$ Grassley Seeks Hedge Fund Registration: Says Congress Needs to Bring About Transparancy, (March 7, 2007). Available at http://grassley.senate.gov/public/index.cfm?FuseAction=PressReleases.View\&PressRelease_id=14b9 e3cd-47db-45d1-bad8-1017d6b18c5f.

${ }^{79}$ Supra Note 19.

${ }^{80}$ Katz David M., Lawmakers: Hedge Fund Risk Hits Pensions, (March 13, 2007). Available at http://www.cfo.com/article.cfm/8844660/c_8913455?f=insidecfo.

${ }^{81}$ Supra Note 18, at 12.
} 


\section{CONCLUSION}

With such strong hedge fund performance and easily recognizable market benefits, absent increasing fraud; why make a change at all? With the hedge fund industry growing to over $\$ 1$ trillion in the last few years, fixing something that isn't broke seems like a good way to screw it up. After all, no amount of regulation will eliminate fraud. ${ }^{82}$ In addition, if registration would have the effect of eliminating fraud and propagating transparency, the retailization of the hedge funds should also be increased.

${ }^{82}$ Supra Note 25. 